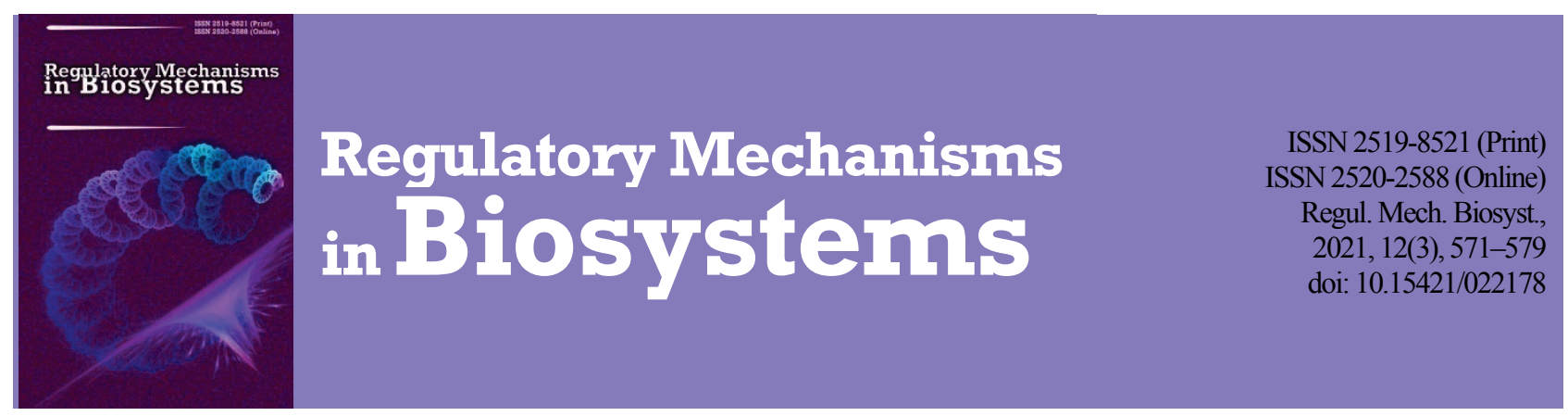

\title{
Prophylaxis of microelementosis in rabbits using a mixture of glauconite, succinic, humic and fulvic acids and minerals
}

\author{
Y. V. Korniichuk, N. H. Grushanska, V. M. Kostenko, T. A. Paliukh, I. F. Makovska \\ National University of Life and Environmental Sciences of Ukraine, Kyiv, Ukraine
}

Article info

Received 09.08.2021

Received in revised form 01.09 .2021

Accepted 02.09.2021

National University

of Life and Environmental

Sciences of Ukraine,

Heroyiv Oborony st., 15 ,

Kyiv, 03041, Ukraine.

Tel.: +38-093-914-61-00.

E-mail:

lisa8919@bigmir.net
Kornïchuk, Y. V., Grushanska, N. H., Kostenko, V. M., Paliukh, T. A., \& Makovska, I. F. (2021). Prophylaxis of microelementosis in rabbits using a mixture of glauconite, succinic, humic and fulvic acids and minerals. Regulatory Mechanisms in Biosystems, 12(3), 571-579. doi:10.15421/022178

Impaired metabolism of mineral substances in the conditions of industrial rabbit breeding may cause decrease in increment of live mass, reduction of immunity, mass morbidity and death of animals. In our experiment, we studied the efficiency of using a mineral mixture to prevent the disorders in the metabolism of rabbits according to changes in morphologic, biochemical parameters and antioxidant status of blood, chemical composition of blood plasma and increments in body weight compared to the control group of animals. For the studies, we formed four groups of white New Zealand rabbits, each comprising six individuals aged 70 days with mean body weight equaling $1.99 \mathrm{~kg}$. In group I, the rabbits received an aqueous form of a mixture of glauconite, succinic acid, humic and fulvic acids and lactates of zinc, manganese, cuprum, cobalt and iron with water, rabbits of group II were given a dry form of a mixture of glauconite, succinic acid, humic and fulvic acids and lactates of zinc, manganese, cuprum, cobalt and iron with fodder, and the rabbits of group III were intramuscularly injected with butanol fraction of humic acids. The experiment lasted for 21 days. The results of the experiment indicate that the most effective prophylaxis of malfunctions of mineral metabolism in white New Zealand rabbits aged 70-95 was dry mixture of glauconite, succinic acid, humic and fulvic acids and lactates of zinc, manganese, cuprum, cobalt and iron with fodder (group II), which was given once a day for 21-day period. We determined a positive effect of biologically active supplement on the parameters of hematopoiesis ( 1.25 times significantly higher level of hemoglobin and 1.14 times higher number of erythrocytes), metabolism of proteins (1.54 times significantly higher content of albumins), mineral substances (significantly higher content of inorganic phosphorus - by 1.17 times, calcium by 2.18 times, manganese by 1.39 times, zinc by 1.50 times, iron by 1.39 times and cuprum by 1.49 times), functional condition of the liver (2.04 times lower activity of gamma-glutamyltransferase), the state of the antioxidant system (lowest catalase activity) and energy of rabbits' growth (1.20-fold increment in body weight). The results of our study indicate that using a dry form of the mixture of glauconite, succinic acid, humic and fulvic acids and lactates of zinc, manganese, cuprum, cobalt and iron with fodder is an efficient method of preventing malfunctioning of mineral metabolism in rabbits.

Keywords: microelements; blood of rabbits; New Zealand white rabbits; atomic emission spectrometry; TBA-active product; catalase.

\section{Introduction}

Rabbits are fast-growing animals and modern industrial rabbit breeding entails slaughter of rabbits aged three months on average. In the conditions of effective industrial rabbit breeding, the diet should be balanced according to all nutrients, including minerals. Imbalanced diet of animals in the conditions of industrial production may impair the mineral metabolism. Specifics of mineral deficiency in the territories of biogeochemical zones and provinces, preparation of fodders for rabbits requires using mineral supplements. Development of effective mineral mixtures for application in industrial rabbit breeding taking into account peculiarities of biogeochemical zones and provinces, the most humane approaches to animals and physiological ways to use the preparations is a relevant topic of research.

Scientists all around the globe seek for, study and develop efficient mineral additives, preparations and biologically active substances for treatment of impaired metabolism in animals, including rabbits (Raafat, 2011; Mista \& Rzasa, 2012; Elokil et al., 2019; Lieshchova et al., 2020). According to most scientists, the most effective way of preventing metabolic disorders in rabbits is use of complex preparations, and therefore the search for them still continues. Rabbits' diet, balanced by such microelements as zinc, cuprum, selenium, manganese, cobalt, iron, promotes correct functioning of protecting mechanisms of the rabbit organism (Ebeid et al., 2013; Abd El-Rahim, 2017; Clauss \& Hatt, 2017). Elokil et al.
(2019) determined a positive effect of supplementing the diet of rabbits with zinc and cuprum on antioxidant properties of the organism of animals and development of essential aminoacids. A similar positive effect on the antioxidant system of the rabbit organism was determined by scientists Tsekhmistrenko \& Fedorchenko $(2015,2016)$ using vitamin-mineral supplement that contained potassium, phosphorus, sodium, cuprum, zinc, manganese, iron, iodine, cobalt and selenium and vitamins $A, D_{3}, E, K_{3}$, $\mathrm{B}_{1}, \mathrm{~B}_{2}, \mathrm{~B}_{3}, \mathrm{~B}_{4}, \mathrm{~B}_{5}, \mathrm{~B}_{6}, \mathrm{~B}_{12}$. Kunkel \& Pearson (1948) determined that magnesium deficiency in the diet of rabbits $(20 \mathrm{mg}$ or less per $100 \mathrm{~g}$ of diet) causes heightened excitability, convulsions, hypomagnesemia and growth retardation, whereas sufficient level of magnesium (30-40 mg per $100 \mathrm{~g}$ of diet) leads to quick recovery of the animals' growth. Mattioli et al. (2020) determined that sufficient level of selenium in rabbits' diet positively influences the parameters of blood plasma and supports the level of iron in the blood of the animals. Shtapenko et al. (2018) reported that adding organic compounds of zinc, manganese, chromium and selenium to the diet of female rabbits led to positive effects on the intensity of metabolic processes in reproductive organs, maintenance of antioxidantperoxide balance, improvement of fertility and embryo implantation. The results of studies by some scientists refute the efficacy of zinc compounds in improving rabbits' increment (Casado et al., 2011). At the same time, Hassan et al. (2021) determined the effectiveness of using zinc-containing supplements for the parameters and antioxidant properties of the rabbits' organism during feeding. Analysis of researches by other scientists re- 
vealed that using such components as humic acids, glauconite and succinic acids positively influences the digestibility of fodder (Hall, 1952), improves digestibility of minerals in the animals' intestine (Filipova, 2019) and when combined with minerals substances they improve productive parameters (tendency towards increase in weight in rabbits and higher coefficient of fodder conversion) and meat quality (increase in iron content in meat) (Mista \& Rzasa, 2012; Maha et al., 2019). Zadnipryany et al. (2019) determined a positive effect of succinic acid on supporting the contraction function of the cardiac muscle. Raafat (2011) revealed that dimercaptosuccinic acid (DMSA) is effective in reducing the intoxication impact of plumbum on the organism of rabbits. Therefore, a promising direction of studies of treatment and prophylaxis of mineral metabolism in rabbits is the use of complex biologically active supplements that contain glauconite, salt of humic acid, succinic acid and microelements.

Peculiarities of biochemical zones and provinces cause deficiency of corresponding substances in fodders and water (Grushanska, 2017). To provide the rabbit organism with minerals, mineral supplements are usually used. To reduce the costs of production, many enterprises prepare combined feeds themselves, adding commercial mineral supplements in doses recommended by the manufacturers. There was performed an analysis of some commercial mineral supplements produced in Ukraine and recommendations of some foreign authors, identifying some differences (Gidenne, 2017; Yan et al., 2017; Abdel-Azeem et al., 2019). Therefore, the diets of rabbits should be corrected taking into account physiological needs of the organism for mineral substances, the corresponding biogeochemical zone and province where the farm is located, and also conditions that accompany the emergence of deficiency (Kiwull-Schöne, 2005; Proença \& Mayer, 2014; Gidenne, 2015).

The objectives of our experiment were peculiarities of the reaction of the organism of white New Zealand rabbits to various forms of mineral mixture for prophylaxis of impaired mineral metabolism.

\section{Materials and methods}

The protocol of the study was approved by the local Committee of Ethics of the National University of Life and Environmental Sciences of Ukraine. All manipulations with animals were performed according to the principles and recommendation of the Management of Monitoring and Use of Laboratory Animals and also the leading principles of the ARRIVE. To perform the study, we selected clinically healthy white New Zealand rabbits. The animals for the study were selected according to the method of pair analogues, randomly, with further division of the groups so the body weight would range no more than $3.0 \%$ from the mean weight within the group. Biological substrates for the study were selected at the beginning and end of our studies according to the general scientific principles and methods.

The studies were carried out at the base of the Faculty of Veterinary Medicine of the National University of Life and Environmental Sciences of Ukraine. The diet of rabbits was balanced according to the main parameters, water provision was centralized, the drinking water was in individual drinkers. After 30-day quarantine, 24 rabbits aged 70 days and weighing $1.99 \pm 0.06 \mathrm{~kg}$ on average were divided into four groups (control, experimental group I, experimental group II, experimental group III) comprising six individuals each. The rabbits were kept individually in cages. Animals of the control group received the main diet in granules in the dose of $0.155 \mathrm{~kg}$ per animal and had free access to drinking water. The fodder mixture $(\mathrm{g} / \mathrm{kg})$ included: Lucerne hay -265 , wheat -140 , sunflower grist -110 , barley -309 , oat -100 , soybean grist -58 , Lumance C (Innovad, Belgium) - 1, chalk - 4, FYS premix (Blenheim House, United Kingdom) -4.5 ( $1 \mathrm{~kg}$ of premix contained $650 \mathrm{~g}$ of calcium carbonate, $30-100 \mathrm{~g}$ of saraponin, $250 \mathrm{~g}$ of oligosaccharide), Klinofeed - 2 (mycotoxin neutralizer based on Klinoptilol and heulanditey), tricalcium phosphate -4 , salt -1.5 , lysine -1 . Together with the main diet, rabbits in experimental group I were once a day additionally given aqueous form of mixture of glauconite, succinic acid, sodium salts of humic and fulvic acids, lactates of zinc, manganese, cuprum, cobalt and iron in the form of $3 \%$ solution in the dose of $0.5 \mathrm{~mL}$ of the mixture per $1 \mathrm{~kg}$ of weight, added to drinking water for 21 days. In experimental group II, the animals received a dry form of a mixture of glauconite, succinic acid, sodium salts of humic and fulvic acids, lactates of zinc, manganese, cuprum, cobalt and iron in the dose of $4 \mathrm{~g}$ of the mixture per $1 \mathrm{~kg}$ of fodder, together with their main diet, for 21 days. In experimental group III, the animals were twice (at the age of 70 and 84 days) intramuscularly injected with butanol fraction of humic acids in the dose of $0.1 \mathrm{~mL}$ per $1 \mathrm{~kg}$ of body weight $(1 \mathrm{~mL}$ of the solution contained $9 \mathrm{mg}$ of butanol fraction of humic acids and additional substances - sodium chloride and water for injections), the animals of this group received the main diet and had free access to water. Daily doses of minerals which were given to one animal in the content of aqueous and dry forms of mixtures equaled: $\mathrm{Zn}-28.7$ $\mathrm{mg}, \mathrm{Mn}-5.7 \mathrm{mg}, \mathrm{Cu}-5.7 \mathrm{mg}, \mathrm{Co}-0.12 \mathrm{mg}$, and $\mathrm{Fe}-28.7 \mathrm{mg}$.

Blood of rabbits was drawn from the marginal ear vein into a disposable test tube after a clinical examination before morning feeding. Blood for studying morphological, biochemical parameters, chemical composition and TBA-active products was stabilized by heparin, transported and stored at the temperature of $4^{\circ} \mathrm{C}$. Using no anticoagulants, we drew blood to study activity of catalase, transported and kept it at the room temperature. Morphological, biochemical parameters and content of chemical elements in blood were studied at the beginning (the first day) and the end (the twenty second day) of the studies. To assess the results of increment of animals, the control weighing was performed in the morning before the first, seventh, fourteenth and twenty second day of the experiment.

General clinical analysis of blood included counting erythrocytes and leukocytes - in the chamber with hemocytometer on Micromed XS-3320 microscope (Micromed, China, 2018); determining content of hemoglobin (hemoglobin cyanide method with acetone cyanohydrin); determining mean corpuscular hemoglobin (MCH); obtaining leukogram using the Filipchenko's counting method. Blood smears were stained using Leucodif 200 (LDF 200) (Erba Lachema s.r.o, the Chechen Republic). Concentration of total protein, albumins, glucose, calcium of total and inorganic phosphorus in blood serum was determined using colorimetric methods, the activities of alkaline phosphatase (AP), aspartate aminotransferase (AST), alanine aminotransferase (ALT) and gamma-glutamyltransferase (GGT) were determined using kinetic technique. The studies were performed on semi-automatic biochemical analyzer Lab Line - 010 (Lab Line, Austria, 2010) using reagents manufactured by Spain Lab Company (Ukraine) and High Technology Inc. (USA). TBA-active products in erythrocytes of blood were determined using Jagi technique modified by Ishihara and Honcharenko (1985) and activity of catalase in blood serum was determined by employing spectrophotometric technique on SF-26 spectrophotometer (LOMO, Russia) using Koroliuk's technique (1988). The method of atomic emission spectrometry within ductively coupled plasma on example of Optima 2100 DV (Perkin Elmer Inc., USA, 2004) was used so as to determine the composition of chemical elements in the blood plasma. The weight gain of the animals was determined by control weighing in the morning and before feeding.

The quantitative data were analyzed using Statistica 6.0 (Stat Soft Inc., USA). To present the data in the tables, we used format $\mathrm{x} \pm \mathrm{SD}(\mathrm{x} \pm$ standard deviation). Using ANOVA criterion, we determined differences between the values of the control and experimental groups where the differences were considered significant at $\mathrm{P}<0.05$.

\section{Results}

Clinical parameters of fattening rabbits during the experiments were within the physiological fluctuations. In morphological parameters of blood content of rabbits of all groups at the beginning of the experiment, there were no differences between the groups, and the parameters were within the physiological norm, though the amount of erythrocytes, content of hemoglobin and mean content of hemoglobin in erythrocytes was approaching the lower physiological threshold (Tables 1,2,3).

At the end of the experiment, all the morphological parameters of blood of rabbits were within the physiological norm, though they underwent changes compared with the results at the beginning of the experiment (Table 4, 5, 6).

After using the aqueous mixture of water, we determined a $19.9 \%$ significantly lower content of hemoglobin in blood of rabbits of group I at the end of the experiment compared with such in group I at the beginning of the study (Table 1), and also determined a $4.3 \%$ higher level of hemog- 
lobin at the end of the study compared with the corresponding parameter of the blood of animals in the control group (Table 4). In the blood of rabbits of group II fed dry mixture of fodder, we determined a $8.4 \%$ significantly higher content of hemoglobin and 1.68 times significantly lower amount of monocytes at the end of the experiment compared with the corresponding parameters of group II at the beginning of the study (Table 2), and also determined a significant 1.25-fold higher content of hemoglobin and a 1.14 times higher number of erythrocytes compared with the corresponding parameters of animals in the control group (Table 5).

Table 1

Morphological blood parameters and hemoglobin content in blood of rabbits in group I which were given mixture of glaukonite, succinic acid, humic and fulvic acids and lactates of zinc, manganese, cuprum, cobalt and iron (before the beginning of and at the end of the experiment, $x \pm S D, n=6$ )

\begin{tabular}{|c|c|c|c|c|}
\hline Parameter & $\begin{array}{c}\text { Reference interval } \\
\text { (Jain, 1986) }\end{array}$ & Start of experiment & End of experiment & $\begin{array}{c}\text { Compared to the start } \\
\text { of experiment, } \%\end{array}$ \\
\hline Erythrocytes, RBC, $10^{12} / \mathrm{L}$ & $5.30-6.24$ & $5.83 \pm 0.14$ & $5.81 \pm 0.19$ & 99.7 \\
\hline Hemoglobin, $\mathrm{Hb}, \mathrm{g} / \mathrm{L}$ & $112-134$ & $120.93 \pm 0.60$ & $109.0 \pm 0.58^{*}$ & 90.2 \\
\hline Mass of hemoglobin in erythrocyte, $\mathrm{MCH}, \mathrm{pg}\left(10^{-12} \mathrm{~g}\right)$ & $21.0-21.5$ & $20.80 \pm 0.40$ & $18.82 \pm 0.56^{* *}$ & 90.5 \\
\hline Leukocytes, WBC, $10^{9} / \mathrm{L}$ & $7.7-9.1$ & $8.20 \pm 0.26$ & $7.67 \pm 0.90$ & 93.5 \\
\hline Basophils, $\%$ & $0.8-3.1$ & $0.3 \pm 0.3$ & $0.7 \pm 0.3$ & 233.3 \\
\hline Eosinophils, \% & $0.9-1.6$ & $1.2 \pm 0.2$ & $1.3 \pm 0.3$ & 108.3 \\
\hline Neutrophils, \% & $25.0-35.9$ & $31.3 \pm 2.4$ & $35.2 \pm 0.8$ & 112.5 \\
\hline Limphocytes, \% & $60.0-67.5$ & $59.8 \pm 2.7$ & $56.2 \pm 1.4$ & 94.0 \\
\hline Monocytes, \% & $1.4-5.6$ & $4.0 \pm 0.2$ & $4.7 \pm 0.3^{* * *}$ & 117.5 \\
\hline
\end{tabular}

Note: $* \mathrm{P}<0.001,{ }^{*} \mathrm{P}<0.01, * * * \mathrm{P}<0.05$-indicate values which reliably differed one from another within one line of table according to the results of comparison using ANOVA.

Table 2

Morphological parameters of blood and content of hemoglobin in blood of rabbits in group II which were given mixture of glauconite, succinic acid, humic and fulvic acids and lactates of zinc, manganese, cuprum, cobalt and iron (before the beginning of and the end of the experiment, $x \pm S D, n=6$ )

\begin{tabular}{|c|c|c|c|c|}
\hline Parameter & $\begin{array}{c}\text { Reference interval } \\
\text { (Jain, 1986) }\end{array}$ & Start of experiment & End of experiment & $\begin{array}{c}\text { Compared to the start } \\
\text { of experiment, } \%\end{array}$ \\
\hline Erythrocytes, $\mathrm{RBC}, 10^{12} / \mathrm{L}$ & $5.30-6.24$ & $5.68 \pm 0.29$ & $6.04 \pm 0.11$ & 106.3 \\
\hline Hemoglobin, $\mathrm{Hb}, \mathrm{g} / \mathrm{L}$ & $112-134$ & $120.30 \pm 0.75$ & $130.38 \pm 1.91 *$ & 108.4 \\
\hline Mass of hemoglobin in erythrocyte, $\mathrm{MCH}, \mathrm{pg}\left(10^{-12} \mathrm{~g}\right)$ & $21.0-21.5$ & $21.39 \pm 1.04$ & $21.61 \pm 0.44$ & 101.0 \\
\hline Leukocytes, WBC, $10^{9} / \mathrm{L}$ & $7.7-9.1$ & $7.78 \pm 0.50$ & $8.50 \pm 0.45$ & 109.3 \\
\hline Basophils, $\%$ & $0.8-3.1$ & $0.7 \pm 0.3$ & $0.3 \pm 0.3$ & 42.9 \\
\hline Eosinophils, \% & $0.9-1.6$ & $1.5 \pm 0.5$ & $0.8 \pm 0.3$ & 53.3 \\
\hline Neutrophils, \% & $25.0-35.9$ & $33.8 \pm 3.6$ & $35.3 \pm 5.2$ & 104.4 \\
\hline Limphocytes, \% & $60.0-67.5$ & $57.0 \pm 4.5$ & $59.3 \pm 5.1$ & 104.0 \\
\hline Monocytes, \% & $1.4-5.6$ & $4.2 \pm 0.3$ & $2.5 \pm 0.4 * *$ & 59.5 \\
\hline
\end{tabular}

Note: see Table 1.

Table 3

Morphological parameters of blood and content of hemoglobin in blood of rabbits in group III which were given butanol fraction of humic acids (before and at the end of the experiment, $\mathrm{x} \pm \mathrm{SD}, \mathrm{n}=6$ )

\begin{tabular}{|c|c|c|c|c|}
\hline Parameter & $\begin{array}{l}\text { Reference interval } \\
\text { (Jain, 1986) }\end{array}$ & Start of experiment & End of experiment & $\begin{array}{l}\text { Compared to the start } \\
\text { of experiment, } \%\end{array}$ \\
\hline Erythrocytes, $\mathrm{RBC}, 10^{12} / \mathrm{L}$ & $5.30-6.24$ & $5.34 \pm 0.13$ & $6.04 \pm 0.04^{*}$ & 113.1 \\
\hline Hemoglobin, $\mathrm{Hb}, \mathrm{g} / \mathrm{L}$ & $112-134$ & $111.73 \pm 0.86$ & $101.62 \pm 0.87 *$ & 91.1 \\
\hline Mass of hemoglobin in erythrocyte, $\mathrm{MCH}, \mathrm{pg}\left(10^{-12} \mathrm{~g}\right)$ & $21.0-21.5$ & $20.98 \pm 0.43$ & $16.83 \pm 0.11^{*}$ & 80.2 \\
\hline Leukocytes, WBC, $10^{9} / \mathrm{L}$ & $7.7-9.1$ & $8.0 \pm 0.15$ & $8.95 \pm 0.55$ & 111.9 \\
\hline Basophils, $\%$ & $0.8-3.1$ & 0 & $1.3 \pm 0.3^{*}$ & - \\
\hline Eosinophils, \% & $0.9-1.6$ & $1.0 \pm 0$ & $1.3 \pm 0.3$ & 130.0 \\
\hline Neutrophils, \% & $25.0-35.9$ & $34.2 \pm 3.1$ & $24.5 \pm 2.0^{* *}$ & 71.6 \\
\hline Limphocytes, \% & $60.0-67.5$ & $59.3 \pm 2.6$ & $68.8 \pm 2.0^{* *}$ & 116.0 \\
\hline Monocytes, \% & $1.4-5.6$ & $2.3 \pm 0.3$ & $3.0 \pm 0.2 * * *$ & 130.4 \\
\hline
\end{tabular}

Note: see Table 1.

Table 4

Morphological parameters of blood and content of hemoglobin in blood of rabbits that were given mixture of glauconite, succinic acid, humic and fulvic acids and lactates of zinc, manganese, cuprum, cobalt and iron in group I and the control group (end of the experiment, $x \pm S D, n=6$ )

\begin{tabular}{|c|c|c|c|c|}
\hline Parameter & $\begin{array}{l}\text { Reference interval } \\
\text { (Jain, 1986) }\end{array}$ & Control & $\begin{array}{l}\text { Group I, aqueous } \\
\text { solution of mix }\end{array}$ & $\begin{array}{l}\text { Compared to } \\
\text { the control, } \%\end{array}$ \\
\hline Erythrocytes, $\mathrm{RBC}, 10^{12} / \mathrm{L}$ & $5.30-6.24$ & $5.29 \pm 0.17$ & $5.81 \pm 0.19^{* * *}$ & 109.8 \\
\hline Hemoglobin, $\mathrm{Hb}, \mathrm{g} / \mathrm{L}$ & $112-134$ & $104.45 \pm 0.35$ & $109.0 \pm 0.58^{*}$ & 104.3 \\
\hline Mass of hemoglobin in erythrocyte, $\mathrm{MCH}, \mathrm{pg}\left(10^{-12} \mathrm{~g}\right)$ & $21.0-21.5$ & $19.82 \pm 0.64$ & $18.82 \pm 0.56$ & 95.0 \\
\hline Leukocytes, WBC, $10^{9} / \mathrm{L}$ & $7.7-9.1$ & $7.48 \pm 0.55$ & $7.67 \pm 0.90$ & 102.5 \\
\hline Basophils, $\%$ & $0.8-3.1$ & 0 & $0.7 \pm 0.3^{* *}$ & - \\
\hline Eosinophils, \% & $0.9-1.6$ & $1.0 \pm 0.0$ & $1.3 \pm 0.3$ & 130.0 \\
\hline Neutrophils, \% & $25.0-35.9$ & $33.7 \pm 1.0$ & $35.2 \pm 0.8$ & 104.5 \\
\hline Limphocytes, $\%$ & $60.0-67.5$ & $58.7 \pm 0.6$ & $56.2 \pm 1.4^{* * *}$ & 95.7 \\
\hline Monocytes, \% & $1.4-5.6$ & $4.3 \pm 1.0$ & $4.7 \pm 0.3$ & 109.3 \\
\hline
\end{tabular}

Note: see Table 1.

At the end of the experiment, in blood of rabbits of group III which had been injected humic acid, we determined the following changes: significant increases by 1.13 times in the number of erythrocytes, by $1.3 \%$ in basophiles and by $1.2 \%$ in lymphocytes, significant decrease by $9.9 \%$ in hemoglobin content and by 1.25 in mean content of hemoglobin in erythrocytes compared with such parameters of group III at the beginning 
of the study (Table 3), and also determined significantly higher number of erythrocytes - by $14.2 \%$, basophiles by $1.3 \%$ and lymphocytes by 1.17 times, significantly lower content of hemoglobin in erythrocytes - by 1.18 times and neutrophils by 1.38 times compared with the corresponding parameters of animals of the control group (Table 6). Blood of rabbits of the control group at the end of the experiment had a significant decrease by $10.3 \%$ in the content of hemoglobin compared with the corresponding parameters in the control group at the beginning of the study. The parameters of biochemical content in blood serum of rabbits of all groups at the beginning of the experiment did not differ between the groups, and also the parameters in all groups were within the physiological norms, though the contents of total protein and albumins were close to the lower physiological threshold (Tables 7, 8, 9). At the end of the experiment, all the studied biochemical parameters in blood serum of rabbits were within the physiological norms, though some changes occurred compared with the beginning of the experiment (Tables 10,11, 12).

Table 5

Morphological parameters of blood and content of hemoglobin in blood of rabbits that were given mixture of glauconite, succinic acid, fulvic acids and lactates of zinc, manganese, cuprum, cobalt and iron in group II and the control group (end of the experiment, $\mathrm{x} \pm \mathrm{SD}, \mathrm{n}=6$ )

\begin{tabular}{|c|c|c|c|c|}
\hline Parameter & $\begin{array}{c}\text { Reference interval } \\
\text { (Jain, 1986) }\end{array}$ & Control & Group II, dry of mix & $\begin{array}{l}\text { Compared to } \\
\text { the control, } \%\end{array}$ \\
\hline Erythrocytes, RBC, $10^{12} / \mathrm{L}$ & $5.30-6.24$ & $5.29 \pm 0.17$ & $6.04 \pm 0.11^{* *}$ & 114.2 \\
\hline Hemoglobin, $\mathrm{Hb}, \mathrm{g} / \mathrm{L}$ & $112-134$ & $104.45 \pm 0.35$ & $130.38 \pm 1.91^{*}$ & 124.8 \\
\hline Mass of hemoglobin in erythrocyte, $\mathrm{MCH}, \mathrm{pg}\left(10^{-12} \mathrm{~g}\right)$ & $21.0-21.5$ & $19.82 \pm 0.64$ & $21.61 \pm 0.44 * * *$ & 109.0 \\
\hline Leukocytes, WBC, $10^{9} / \mathrm{L}$ & $7.7-9.1$ & $7.48 \pm 0.55$ & $8.50 \pm 0.45$ & 113.6 \\
\hline Basophils, $\%$ & $0.8-3.1$ & 0.0 & $0.3 \pm 0.3$ & - \\
\hline Eosinophils, \% & $0.9-1.6$ & $1.0 \pm 0.0$ & $0.8 \pm 0.3$ & 80.0 \\
\hline Neutrophils, \% & $25.0-35.9$ & $33.7 \pm 1.0$ & $35.3 \pm 5.2$ & 104.7 \\
\hline Limphocytes, $\%$ & $60.0-67.5$ & $58.7 \pm 0.6$ & $59.3 \pm 5.1$ & 101.0 \\
\hline Monocytes, \% & $1.4-5.6$ & $4.3 \pm 1.0$ & $2.5 \pm 0.4$ & 58.1 \\
\hline
\end{tabular}

Note: see Table 1.

Table 6

Morphological parameters of blood and content of hemoglobin in blood of rabbits that were fed with butanol fraction of humic acids in group III and the control group (end of the experiment, $\mathrm{x} \pm \mathrm{SD}, \mathrm{n}=6$ )

\begin{tabular}{|c|c|c|c|c|}
\hline Parameter & $\begin{array}{l}\text { Reference interval } \\
\text { (Jain, 1986) }\end{array}$ & Control & $\begin{array}{l}\text { Group III, humic } \\
\text { acids for injection }\end{array}$ & $\begin{array}{l}\text { Compared to } \\
\text { the control, } \%\end{array}$ \\
\hline Erythrocytes, $\mathrm{RBC}, 10^{12} / \mathrm{L}$ & $5.30-6.24$ & $5.29 \pm 0.17$ & $6.04 \pm 0.04^{*}$ & 114.2 \\
\hline Hemoglobin, $\mathrm{Hb}, \mathrm{g} / \mathrm{L}$ & $112-134$ & $104.45 \pm 0.35$ & $101.62 \pm 0.87 * *$ & 97.2 \\
\hline Mass of hemoglobin in erythrocyte, $\mathrm{MCH}, \mathrm{pg}\left(10^{-12} \mathrm{~g}\right)$ & $21.0-21.5$ & $19.82 \pm 0.64$ & $16.83 \pm 0.11^{*}$ & 84.9 \\
\hline Leukocytes, WBC, $10^{9} / \mathrm{L}$ & $7.7-9.1$ & $7.48 \pm 0.55$ & $8.95 \pm 0.55$ & 119.7 \\
\hline Basophils, \% & $0.8-3.1$ & 0 & $1.3 \pm 0.3^{*}$ & - \\
\hline Eosinophils, \% & $0.9-1.6$ & $1.0 \pm 0.0$ & $1.3 \pm 0.3$ & 130.0 \\
\hline Neutrophils, $\%$ & $25.0-35.9$ & $33.7 \pm 1.0$ & $24.5 \pm 2.0^{* *}$ & 72.7 \\
\hline Limphocytes, \% & $60.0-67.5$ & $58.7 \pm 0.6$ & $68.8 \pm 2.0^{*}$ & 117.2 \\
\hline Monocytes, $\%$ & $1.4-5.6$ & $4.3 \pm 1.0$ & $3.0 \pm 0.2$ & 69.8 \\
\hline
\end{tabular}

Note: see Table 1.

Table 7

Biochemical parameters of blood serum of rabbits that were given mixture of glauconite, succinic acid, humic and fulvic acids and lactates of zink, manganese, cuprum, cobalt and iron in group I (before the experiment and at the end of the experiment, $x \pm S D, n=6$ )

\begin{tabular}{|c|c|c|c|c|}
\hline Parameter & $\begin{array}{l}\text { Reference interval } \\
\text { (Carpenter, 2018) }\end{array}$ & Start of experiment & End of experiment & $\begin{array}{l}\text { Compared to the start } \\
\text { of experiment, } \%\end{array}$ \\
\hline Protein, total, $\mathrm{g} / \mathrm{L}$ & $54-75$ & $55.37 \pm 0.15$ & $61.78 \pm 0.77^{*}$ & 111.6 \\
\hline Albumin, $\mathrm{g} / \mathrm{L}$ & $25-50$ & $25.73 \pm 1.36$ & $26.58 \pm 0.20$ & 103.3 \\
\hline Glucose, mmol/L & $4.16-8.33$ & $6.86 \pm 0.62$ & $4.63 \pm 0.04 * *$ & 67.5 \\
\hline Calcium, $\mathrm{mmol} / \mathrm{L}$ & $2.0-3.70$ & $3.0 \pm 0.17$ & $2.54 \pm 0.02 * * *$ & 84.7 \\
\hline Phosphorus, mmol/L & $0.74-2.23$ & $1.41 \pm 0.15$ & $1.79 \pm 0.01 * * *$ & 127.0 \\
\hline Urea nitrogen, $\mathrm{mmol} / \mathrm{L}$ & $2.50-8.33$ & $4.0 \pm 0.47$ & $3.60 \pm 0.52$ & 90.0 \\
\hline Creatinine, $\mathrm{mcmol} / \mathrm{L}$ & $44.20-229.84$ & $54.57 \pm 7.77$ & $51.07 \pm 2.28$ & 93.6 \\
\hline Alkaline phosphatase, ALP, U/L & $4.0-70$ & $32.93 \pm 4.95$ & $27.75 \pm 1.61$ & 84.3 \\
\hline Aspartate aminotransferase, AST, U/L & $14-113$ & $16.83 \pm 1.89$ & $21.05 \pm 2.27$ & 125.1 \\
\hline Alanine aminotransaminase, ALT, U/L & $14-80$ & $36.22 \pm 5.37$ & $39.06 \pm 2.35$ & 107.8 \\
\hline Gamma-glutamyl transpeptidase, g-GT, U/L & $0-7$ & $5.97 \pm 0.44$ & $4.86 \pm 0.48^{* * *}$ & 81.4 \\
\hline Bilinubin total, $\mathrm{mcmol} / \mathrm{L}$ & $0-12.83$ & $6.73 \pm 0.28$ & $6.60 \pm 0.26$ & 98.1 \\
\hline
\end{tabular}

Note: see Table 1.

In blood serum of rabbits of group I, after consuming aqueous mixture with water, we determined significant 1.12 times higher total protein, 1.48 times significantly lower content of glucose at the end of the experiment compared with the same parameters of group I at the beginning of the experiment (Table 7), and also determined significantly higher levels of the following parameters: total protein - by 1.12 times, glucose - by $8.2 \%$, inorganic phosphorus - by 1.11 times, significantly lower content of creatinine - by 1.61 times and GGT by 1.38 times compared with the corresponding parameters in blood of animals of the control group (Table 10). In blood serum of rabbits of group II fed the dry mixture with fodder, at the end of the experiment, we determined significantly higher content of total protein by 1.12 times, albumins by 1.45 times, inorganic phosphorus by 1.36 times, urea by 2.30 times, creatinine by 1.59 times, and significantly lower content of glucose by 1.42 times, total calcium by 1.20 times, alkaline phosphatase by 1.65 times and GGT by 1.65 times, compared with such parameters of group II at the beginning of the experiment (Table 8 ), and also determined significantly higher content of albumins by 1.54 times, inorganic phosphorus by 1.17 times, urea by 1.76 times, creatinine by 1.26 times and significantly lower content of total calcium by 1.12 times and GGT by 2.04 times compared with the corresponding parameters of animals of the control group (Table 11). After injecting humic acids, at the end of the experiment, blood serum of rabbits of group III had a significantly lower level of glucose by 1.31 times, total calcium by 1.20 times, urea by 1.18 times, ALT by 1.75 times, a signi- 
ficantly higher content of inorganic phosphorus by 1.39 times, AP by 1.31 times, AST by 1.48 times compared with such parameters of group III at the beginning of the experiment (Table 9), and also significantly higher level of inorganic phosphorus by 1.16 times, AP by 1.28 times, significantly lower level of creatinine by 1.69 times and ALT by 1.74 times compared with such of the control group (Tables 12). At the end of the experiment, in blood of rabbits of the control group, we saw significant decreases in content of glucose by 1.24 times, significantly higher level of inorganic phosphorus by 1.14 times, AST by 2.27 times and GGT by 1.37 times compared with such of the control group at the beginning of the experiment.

Table 8

Biochemical parameters of blood serum of rabbits that were given mixture of glauconite, succinic acid, humic and fulvic acids and lactates of zinc, manganese, cuprum, cobalt and iron in group II (before and at the end of the experiment, $x \pm S D, n=6$ )

\begin{tabular}{lccc}
\hline \multicolumn{1}{c}{ Parameter } & $\begin{array}{c}\text { Reference interval } \\
\text { (Carpenter, 2018) }\end{array}$ & Start of experiment & $\begin{array}{c}\text { Compared to the start } \\
\text { of experiment, } \%\end{array}$ \\
\hline Protein, total, g/L & $54-75$ & $55.52 \pm 1.65$ & $\begin{array}{c}\text { End experiment } \\
\text { Albumin, g/L }\end{array}$ \\
Glucose, $\mathrm{mmol} / \mathrm{L}$ & $25-50$ & $27.28 \pm 1.11$ & $39.52 \pm 1.46^{* *}$ \\
Calcium, mmol/L & $4.16-8.33$ & $6.47 \pm 0.59$ & $4.57 \pm 0.14^{* *}$ \\
Phosphorus, $\mathrm{mmol} / \mathrm{L}$ & $2.0-3.70$ & $2.78 \pm 0.10$ & $2.32 \pm 0.05^{*}$ \\
Urea nitrogen, mmol/L & $0.74-2.23$ & $1.40 \pm 0.11$ & $1.90 \pm 0.04^{* *}$ \\
Creatinine, mcmol/L & $2.50-8.33$ & $3.07 \pm 0.11$ & $7.07 \pm 0.88^{* *}$ \\
Alkaline phosphatase, ALP, U/L & $44.20-229.84$ & $64.92 \pm 10.92$ & $103.35 \pm 4.31^{* *}$ \\
Aspartate aminotransferase, AST, U/L & $4.0-70$ & $37.50 \pm 3.67$ & $22.75 \pm 3.47^{* *}$ \\
Alanine aminotransaminase, ALT, U/L & $14-113$ & $20.12 \pm 1.90$ & $16.45 \pm 3.68$ \\
Gamma-glutamyl transpeptidase, g-GT, U/L & $14-80$ & $39.07 \pm 5.75$ & $32.78 \pm 4.32$ \\
Bilinubin total, mcmol/L & $0-7$ & $4.95 \pm 0.46$ & 135.7 \\
\hline
\end{tabular}

Note: see Table 1.

Table 9

Biochemical parameters of blood serum in rabbits that were given butanol fraction of humic acids in group III (before and at the end of the experiment, $\mathrm{x} \pm \mathrm{SD}, \mathrm{n}=6$ )

\begin{tabular}{|c|c|c|c|c|}
\hline Parameter & $\begin{array}{l}\text { Reference interval } \\
\text { (Carpenter, 2018) }\end{array}$ & Start of experiment & End of experiment & $\begin{array}{l}\text { Compared to the start } \\
\text { of experiment, } \%\end{array}$ \\
\hline Protein, total, $g / \mathrm{L}$ & $54-75$ & $55.58 \pm 0.68$ & $56.85 \pm 1.34$ & 102.3 \\
\hline Albumin, $\mathrm{g} / \mathrm{L}$ & $25-50$ & $25.57 \pm 0.27$ & $25.97 \pm 0.26$ & 101.6 \\
\hline Glucose, $\mathrm{mmol} / \mathrm{L}$ & $4.16-8.33$ & $5.69 \pm 0.15$ & $4.34 \pm 0.06^{*}$ & 76.3 \\
\hline Calcium, $\mathrm{mmol} / \mathrm{L}$ & $2.0-3.70$ & $2.83 \pm 0.03$ & $2.35 \pm 0.05^{*}$ & 83.0 \\
\hline Phosphorus, mmol/L & $0.74-2.23$ & $1.35 \pm 0.01$ & $1.88 \pm 0.01^{*}$ & 139.3 \\
\hline Urea nitrogen, $\mathrm{mmol} / \mathrm{L}$ & $2.50-8.33$ & $4.70 \pm 0.15$ & $4.0 \pm 0.07^{* *}$ & 85.1 \\
\hline Creatinine, $\mathrm{mcmol} / \mathrm{L}$ & $44.20-229.84$ & $53.67 \pm 0.88$ & $48.57 \pm 2.54 * * *$ & 90.5 \\
\hline Alkaline phosphatase, ALP, U/L & $4.0-70$ & $28.22 \pm 1.57$ & $36.91 \pm 1.15^{*}$ & 130.8 \\
\hline Aspartate aminotransferase, AST, U/L & $14-113$ & $15.33 \pm 1.0$ & $22.73 \pm 0.88^{*}$ & 148.3 \\
\hline Alanine aminotransaminase, ALT, U/L & $14-80$ & $28.60 \pm 2.76$ & $16.38 \pm 1.34 * *$ & 57.3 \\
\hline Gamma-glutamyl transpeptidase, g-GT, U/L & $0-7$ & $6.23 \pm 0.08$ & $6.75 \pm 0.36$ & 108.3 \\
\hline Bilinubin total, $\mathrm{mcmol} / \mathrm{L}$ & $0-12.83$ & $6.18 \pm 0.07$ & $6.35 \pm 0.08$ & 102.8 \\
\hline
\end{tabular}

Bilinubin total, $\mathrm{mcmol} / \mathrm{L}$

$0-12.83$ $6.18 \pm 0.07$

Note: see Table 1 .

\section{Table 10}

Biochemical parameters of blood serum of rabbits that were given mixture of glauconite, succinic acid, humic and fulvic acids and lactates of zinc, manganese, cuprum, cobalt and iron in group I and the control group (end of the experiment, $\mathrm{x} \pm \mathrm{SD}, \mathrm{n}=6$ )

\begin{tabular}{|c|c|c|c|c|}
\hline Parameter & $\begin{array}{l}\text { Reference interval } \\
\text { (Carpenter, 2018) }\end{array}$ & Control & $\begin{array}{l}\text { Group I, aqueous } \\
\text { solution of mix }\end{array}$ & $\begin{array}{l}\text { Compared to } \\
\text { the control, } \%\end{array}$ \\
\hline Protein, total, $\mathrm{g} / \mathrm{L}$ & $54-75$ & $55.37 \pm 0.90$ & $61.78 \pm 0.77^{*}$ & 111.6 \\
\hline Albumin, $g / \mathrm{L}$ & $25-50$ & $25.60 \pm 0.32$ & $26.58 \pm 0.20^{* *}$ & 103.8 \\
\hline Glucose, $\mathrm{mmol} / \mathrm{L}$ & $4.16-8.33$ & $4.28 \pm 0.06$ & $4.63 \pm 0.04^{*}$ & 108.2 \\
\hline Calcium, $\mathrm{mmol} / \mathrm{L}$ & $2.0-3.70$ & $2.60 \pm 0.04$ & $2.54 \pm 0.02$ & 97.7 \\
\hline Phosphorus, $\mathrm{mmol} / \mathrm{L}$ & $0.74-2.23$ & $1.62 \pm 0.02$ & $1.79 \pm 0.01^{*}$ & 110.5 \\
\hline Urea nitrogen, $\mathrm{mmol} / \mathrm{L}$ & $2.50-8.33$ & $4.02 \pm 0.16$ & $3.60 \pm 0.52$ & 89.6 \\
\hline Creatinine, $\mathrm{mcmol} / \mathrm{L}$ & $44.20-229.84$ & $81.98 \pm 3.07$ & $51.07 \pm 2.28^{*}$ & 62.3 \\
\hline Alkaline phosphatase, ALP, U/L & $4.0-70$ & $28.77 \pm 0.26$ & $27.75 \pm 1.61$ & 96.5 \\
\hline Aspartate aminotransferase, AST, U/L & $14-113$ & $34.98 \pm 5.82$ & $21.05 \pm 2.27 * * *$ & 60.2 \\
\hline Alanine aminotransaminase, ALT, U/L & $14-80$ & $28.47 \pm 2.62$ & $39.06 \pm 2.35^{* *}$ & 137.2 \\
\hline Gamma-glutamyl transpeptidase, g-GT, U/L & $0-7$ & $6.72 \pm 0.20$ & $4.86 \pm 0.48^{* *}$ & 72.3 \\
\hline Bilinubin total, $\mathrm{mcmol} / \mathrm{L}$ & $0-12.83$ & $6.53 \pm 0.29$ & $6.60 \pm 0.26$ & 101.1 \\
\hline
\end{tabular}

Note: see Table 1.

In blood plasma of rabbits of all groups at the beginning of the experiment, no significant differences were found between the groups according to the chemical composition (Tables 13, 14, 15).

In blood plasma of rabbits of group I, after intake of aqueous mixture with water, we determined a significantly higher concentration of calcium by 1.25 times, manganese by 1.83 times, cobalt by 2.38 times and magnesium by 1.35 times at the end of the experiment compared with such of group I at the start of the experiment (Table 13), and no significant changes were determined at the end of the experiment compared to the control group (Table 16). In blood plasma of rabbits of group II, after intake of the dry mixture, we determined a significantly higher concentration of calcium by 2.34 times, manganese by 3.60 times, zinc by 1.63 times, cobalt by 2.56 times and cuprum by 1.75 times at the end of the experiment compared with such of group II at the beginning of the experiment (Table 14), and also detected a significantly higher concentration of calcium by 2.18 times, manganese by 1.39 times, zinc by 1.50 times, iron by 1.39 times and cuprum by 1.49 times compared with such of animals of the control group (Table 17). 
Table 11

Biochemical parameters of blood serum of rabbits that were given mixture of glauconite, succinic acid, humic and fulvic acids and lactates of zinc, manganese, cuprum, cobalt and iron in group II and the control group (end of the experiment, $\mathrm{x} \pm \mathrm{SD}, \mathrm{n}=6$ )

\begin{tabular}{|c|c|c|c|c|}
\hline Parameter & $\begin{array}{l}\text { Reference interval } \\
\text { (Carpenter, 2018) }\end{array}$ & Control & Group II, dry of mix & $\begin{array}{l}\text { Compared to } \\
\text { the control, } \%\end{array}$ \\
\hline Protein, total, $g / \mathrm{L}$ & $54-75$ & $55.37 \pm 0.90$ & $61.97 \pm 1.46^{* *}$ & 111.9 \\
\hline Albumin, $\mathrm{g} / \mathrm{L}$ & $25-50$ & $25.60 \pm 0.32$ & $39.52 \pm 1.93 *$ & 154.4 \\
\hline Glucose, $\mathrm{mmol} / \mathrm{L}$ & $4.16-8.33$ & $4.28 \pm 0.06$ & $4.57 \pm 0.14$ & 106.8 \\
\hline Calcium, $\mathrm{mmol} / \mathrm{L}$ & $2.0-3.70$ & $2.60 \pm 0.04$ & $2.32 \pm 0.05^{*}$ & 89.2 \\
\hline Phosphorus, mmol/L & $0.74-2.23$ & $1.62 \pm 0.02$ & $1.90 \pm 0.04^{*}$ & 117.3 \\
\hline Urea nitrogen, $\mathrm{mmol} / \mathrm{L}$ & $2.50-8.33$ & $4.02 \pm 0.16$ & $7.07 \pm 0.88^{* *}$ & 175.9 \\
\hline Creatinine, $\mathrm{mcmol} / \mathrm{L}$ & $44.20-229.84$ & $81.98 \pm 3.07$ & $103.35 \pm 4.31 * *$ & 126.1 \\
\hline Alkaline phosphatase, ALP, U/L & $4.0-70$ & $28.77 \pm 0.26$ & $22.75 \pm 3.47$ & 79.1 \\
\hline Aspartate aminotransferase, AST, U/L & $14-113$ & $34.98 \pm 5.82$ & $16.45 \pm 3.68^{* *}$ & 47.0 \\
\hline Alanine aminotransaminase, ALT, U/L & $14-80$ & $28.47 \pm 2.62$ & $32.78 \pm 4.32$ & 115.1 \\
\hline Gamma-glutamyl transpeptidase, g-GT, U/L & $0-7$ & $6.72 \pm 0.20$ & $3.29 \pm 0.13^{*}$ & 49.0 \\
\hline Bilinubin total, $\mathrm{mcmol} / \mathrm{L}$ & $0-12.83$ & $6.53 \pm 0.29$ & $6.58 \pm 0.27$ & 100.8 \\
\hline
\end{tabular}

Note: see Table 1.

Table 12

Biochemical parameters of blood serum of rabbits that were given butanol fraction of humic acid in group III and the control group (end of the experiment, $\mathrm{x} \pm \mathrm{SD}, \mathrm{n}=6$ )

\begin{tabular}{lccc}
\hline \multicolumn{1}{c}{ Parameter } & $\begin{array}{c}\text { Reference interval } \\
\text { (Carpenter, 2018) }\end{array}$ & Control & $\begin{array}{c}\text { Group III, humic acids } \\
\text { for injection }\end{array}$ \\
\hline Protein, total, g/L & $54-75$ & $\begin{array}{c}\text { Compared to } \\
\text { the control, } \%\end{array}$ \\
Albumin, g/L & $25-50$ & $55.37 \pm 0.90$ & $56.85 \pm 1.34$ \\
Glucose, $\mathrm{mmol} / \mathrm{L}$ & $4.16-8.33$ & $25.60 \pm 0.32$ & $25.97 \pm 0.26$ \\
Calcium, $\mathrm{mmol} / \mathrm{L}$ & $2.0-3.70$ & $4.28 \pm 0.06$ & $4.34 \pm 0.06$ \\
Phosphorus, $\mathrm{mmol} / \mathrm{L}$ & $0.74-2.23$ & $2.60 \pm 0.04$ & $2.35 \pm 0.05^{*}$ \\
Urea nitrogen, mmol/L & $2.50-8.33$ & $1.62 \pm 0.02$ & $1.88 \pm 0.01^{*}$ \\
Creatinine, mcmol/L & $44.20-229.84$ & $4.02 \pm 0.16$ & $4.00 \pm 0.07$ \\
Alkaline phosphatase, ALP, U/L & $4.0-70$ & $81.98 \pm 3.07$ & $48.57 \pm 2.54^{*}$ \\
Aspartate aminotransferase, AST, U/L & $14-113$ & $28.77 \pm 0.26$ & $36.91 \pm 1.15^{*}$ \\
Alanine aminotransaminase, ALT, U/L & $14-80$ & $34.98 \pm 5.82$ & $22.73 \pm 0.88^{* * *}$ \\
Gamma-glutamyl transpeptidase, g-GT, U/L & $0-7$ & $28.47 \pm 2.62$ & 116.1 \\
Bilinubin total, memol/L & $0-12.83$ & $6.72 \pm 0.20$ & 59.5 \\
\hline
\end{tabular}

Note: see Table 1.

\section{Table 13}

Content of chemical elements in blood plasma of rabbits after intake of mixture of glauconite, succinic, humic and fulvic acids and lactates of zinc, manganese, cuprum, cobalt and iron in group I (before and at the end of the experiment, $\mathrm{x} \pm \mathrm{SD}, \mathrm{n}=6$ )

\begin{tabular}{lccc}
\hline Parameter & Start of experiment & End of experiment & $\begin{array}{c}\text { Compared to the start } \\
\text { of experiment, \% }\end{array}$ \\
\hline Calcium & $58.6 \pm 2.7$ & $73.3 \pm 4.1^{* *}$ & 125.0 \\
Manganese & $0.0092 \pm 0.0011$ & $0.0168 \pm 0.0007^{*}$ & 182.6 \\
Zinc & $1.84 \pm 0.11$ & $2.05 \pm 0.12$ & 111.4 \\
Iron & $0.67 \pm 0.03$ & $0.67 \pm 0.02$ & 100.0 \\
Cobalt & $0.0021 \pm 0.0004$ & $0.0067 \pm 0.0012^{* *}$ & 319.1 \\
Copper & $0.43 \pm 0.06$ & $0.51 \pm 0.03$ & 118.6 \\
Magnesium & $8.82 \pm 0.33$ & $11.89 \pm 0.58^{*}$ & 134.8 \\
\hline
\end{tabular}

Note: see Table 1 .

\section{Table 14}

Content of chemical elements in blood plasma of rabbits after intake of mixture of glauconite, succinic, humic, fulvic acids and lactates of zinc, manganese, cuprum, cobalt and iron in group II (before and at the end of the experiment, $\mathrm{x} \pm \mathrm{SD}, \mathrm{n}=6$ )

\begin{tabular}{lccc}
\hline Parameter & Start of experiment & End of experiment & $\begin{array}{c}\text { Compared to the start } \\
\text { of experiment, \% }\end{array}$ \\
\hline Calcium & $57.4 \pm 1.6$ & $134.3 \pm 6.0^{*}$ & 233.9 \\
Manganese & $0.0063 \pm 0.0008$ & $0.0227 \pm 0.0017^{*}$ & 360.3 \\
Zinc & $1.80 \pm 0.16$ & $2.93 \pm 0.14^{*}$ & 162.8 \\
Iron & $0.81 \pm 0.07$ & $0.85 \pm 0.05$ & 104.9 \\
Cobalt & $0.0034 \pm 0.0005$ & $0.0087 \pm 0.0011^{* *}$ & 255.9 \\
Copper & $0.40 \pm 0.03$ & $0.70 \pm 0.05^{*}$ & 175.0 \\
Magnesium & $9.30 \pm 0.44$ & $13.92 \pm 2.08^{* * *}$ & 149.7 \\
\hline
\end{tabular}

Note: see Table 1

In blood plasma of rabbits of group III after intake of humic acids, we determined a significantly lower concentration of calcium by 1.35 times, cuprum by 1.66 times and magnesium by 1.25 times, a significantly high- er concentration of manganese by 2.0 times at the end of the experiment, compared with such of group III at the start of the experiment (Table 15), and also a significantly lower concentration of calcium by 1.33 times, zinc by 1.33 times, cobalt by 1.54 times and magnesium by 1.49 times compared with such of the control group (Table 18).

\section{Table 15}

Content of chemical elements in blood plasma of rabbits that consumed butanol fraction of humic acids in group III (before and at the end of the experiment, $\mathrm{x} \pm \mathrm{SD}, \mathrm{n}=6$ )

\begin{tabular}{lccc}
\hline Parameter & Start of experiment & End of experiment & $\begin{array}{c}\text { Compared to the start } \\
\text { of experiment, \% }\end{array}$ \\
\hline Calcium & $62.6 \pm 0.3$ & $46.4 \pm 2.0^{*}$ & 74.1 \\
Manganese & $0.0087 \pm 0.0007$ & $0.0173 \pm 0.0013^{*}$ & 198.9 \\
Zinc & $1.83 \pm 0.14$ & $1.47 \pm 0.10^{* * *}$ & 80.3 \\
Iron & $0.89 \pm 0.08$ & $0.70 \pm 0.01^{* * *}$ & 78.7 \\
Cobalt & $0.0042 \pm 0.0002$ & $0.0046 \pm 0.0005$ & 109.5 \\
Copper & $0.53 \pm 0.03$ & $0.32 \pm 0.02^{*}$ & 60.4 \\
Magnesium & $10.0 \pm 0.09$ & $7.98 \pm 0.38^{* *}$ & 79.8 \\
\hline
\end{tabular}

Note: see Table 1

In the blood of rabbits of the control group, concentration of manganese was significantly higher by 1.79 times, concentration of iron significantly decreased by 1.28 times at the end of the experiment compared with such of the control group at the beggining (Table 5, 6).

Before the experiment, in the content of TBA-active products in erythrocytes and catalase in blood serum of rabbits, we found no significant differences between the groups of animals. Before the beginning of the experiment, content of TBA-active products in erythrocytes was $36.84 \pm$ $0.61 \mathrm{mmol} / \mathrm{L}$ in the control group, $40.11 \pm 2.55 \mathrm{mmol} / \mathrm{L}$ in group I, $43.93 \pm 3.73 \mathrm{mmol} / \mathrm{L}$ in group II and $38.79 \pm 1.01 \mathrm{mmol} / \mathrm{L}$ in group III. Prior to the experiment, catalase content in blood serum was $9.11 \pm$ $0.74 \mathrm{mkat} / \mathrm{L}$ in the control group, $9.64 \pm 0.68 \mathrm{mkat} / \mathrm{L}$ in group I, $9.70 \pm$ $0.81 \mathrm{mkat} / \mathrm{L}$ in group II and $9.86 \pm 0.62 \mathrm{mkat} / \mathrm{L}$ in group III. At the end of the experiment, the content of TBA-active products in erythrocytes was 
$34.09 \pm 0.49 \mathrm{mmol} / \mathrm{L}$ in the control group, $42.45 \pm 1.33 \mathrm{mmol} / \mathrm{L}$ in group I, $41.55 \pm 2.35 \mathrm{mmol} / \mathrm{L}$ in group II and $48.64 \pm 2.03 \mathrm{mmol} / \mathrm{L}$ in group III. At the end of the experiment, the content of catalase was $9.85 \pm$ $0.21 \mathrm{mkat} / \mathrm{L}$ in the control group, $10.76 \pm 0.27 \mathrm{mkat} / \mathrm{L}$ in group I, $7.40 \pm$ $0.85 \mathrm{mkat} / \mathrm{L}$ in group II and $10.44 \pm 0.33 \mathrm{mkat} / \mathrm{L}$ in group III. In erythrocytes of the blood of rabbits of group I, after intake of aqueous mixture with water, concentration of TBA-active products was determined to be significantly higher by 1.25 times at the end of the experiment compared with such of animals of the control group. In blood serum of rabbits of group II fed dry mixture with fodder, concentration of catalase was significantly lower by 1.3 times at the end of the experiment compared with the corresponding parameter of group II at the start of the experiment (Tables 7, 8), and also by 1.3 times compared with such of animals of the control group. In erythrocytes of blood of rabbits of group III which had been injected humic acid, the concentration of TBA-active products in erythrocytes at the end of the experiment was significantly higher by 1.25 times than at the beginning, and also 1.43-fold greater than the concentration of TBA-active products in erythrocytes in the control group. The level of TBA-active products in erythrocytes of animals of the control group significantly decreased by $8.1 \%$ compared with the beginning of the experiment (Tables 7,8).

\section{Table 16}

Content of chemical elements in blood plasma of rabbits that consumed a mixture of glauconite, succinic, humic and fulvic acids and lactates of zinc, manganese, cuprum, cobalt and iron in group I and the control group (end of the experiment, $\mathrm{x} \pm \mathrm{SD}, \mathrm{n}=6$ )

\begin{tabular}{lccc}
\hline Parameter & Control & $\begin{array}{c}\text { Group I, aqueous } \\
\text { solution of mix }\end{array}$ & $\begin{array}{c}\text { Compared to the } \\
\text { control, } \%\end{array}$ \\
\hline Calcium & $61.7 \pm 2.9$ & $73.3 \pm 4.1^{* * *}$ & 118.8 \\
Manganese & $0.0163 \pm 0.0006$ & $0.0168 \pm 0.0007$ & 103.1 \\
Zinc & $1.95 \pm 0.02$ & $2.05 \pm 0.12$ & 105.1 \\
Iron & $0.61 \pm 0.03$ & $0.67 \pm 0.03$ & 109.8 \\
Cobalt & $0.0071 \pm 0.0006$ & $0.0067 \pm 0.0012$ & 94.4 \\
Copper & $0.47 \pm 0.02$ & $0.51 \pm 0.03$ & 108.5 \\
Magnesium & $11.92 \pm 0.77$ & $11.89 \pm 0.58$ & 99.8 \\
\hline
\end{tabular}

Note: see Table 1.

Table 17

Content of chemical elements in blood plasma of rabbits who consumed a mixture of glauconite, succinic, humic, fulvic acids and lactates of zinc, manganese, cuprum, cobalt and iron in group II and the control (end of the experiment, $\mathrm{x} \pm \mathrm{SD}, \mathrm{n}=6$ )

\begin{tabular}{lccc}
\hline \multicolumn{1}{c}{ Parameter } & Control & $\begin{array}{c}\text { Group II, } \\
\text { dry of mix }\end{array}$ & $\begin{array}{c}\text { Compared to } \\
\text { the control, } \%\end{array}$ \\
\hline Calcium & $61.7 \pm 2.9$ & $134.3 \pm 6.0^{*}$ & 1117.9 \\
Manganese & $0.0163 \pm 0.0006$ & $0.0227 \pm 0.0017^{* *}$ & 139.3 \\
Zinc & $1.95 \pm 0.02$ & $2.93 \pm 0.14^{*}$ & 150.3 \\
Iron & $0.61 \pm 0.03$ & $0.85 \pm 0.05^{*}$ & 139.3 \\
Cobalt & $0.0071 \pm 0.0006$ & $0.0087 \pm 0.0011$ & 122.5 \\
Copper & $0.47 \pm 0.02$ & $0.70 \pm 0.05^{* *}$ & 148.9 \\
Magnesium & $11.92 \pm 0.77$ & $13.92 \pm 2.08$ & 116.8 \\
\hline
\end{tabular}

Note: see Table 1.

Table 18

Content of chemical elements in blood plasma of rabbits given butanol fraction of humic acids in group III and the control group (end of the experiment, $\mathrm{x} \pm \mathrm{SD}, \mathrm{n}=6$ )

\begin{tabular}{lccc}
\hline \multicolumn{1}{c}{ Parameter } & Control & $\begin{array}{c}\text { Group III, humic } \\
\text { acids for injection }\end{array}$ & $\begin{array}{c}\text { Compared to } \\
\text { the control, } \%\end{array}$ \\
\hline Calcium & $61.7 \pm 2.9$ & $46.4 \pm 2.0^{*}$ & 75.2 \\
Manganese & $0.0163 \pm 0.0006$ & $0.0173 \pm 0.0013$ & 106.1 \\
Zinc & $1.95 \pm 0.02$ & $1.47 \pm 0.10^{* *}$ & 75.4 \\
Iron & $0.61 \pm 0.03$ & $0.70 \pm 0.01^{* *}$ & 114.8 \\
Cobalt & $0.0071 \pm 0.0006$ & $0.0046 \pm 0.0005^{* *}$ & 64.8 \\
Copper & $0.47 \pm 0.02$ & $0.32 \pm 0.02^{*}$ & 68.1 \\
Magnesium & $11.92 \pm 0.77$ & $7.98 \pm 0.38^{*}$ & 67.0 \\
\hline
\end{tabular}

Note: see Table 1.

Increment in body weight of rabbits throughout the experiment (21 days) was $19.3 \%(0.367 \pm 0.044 \mathrm{~kg})$ in the control group, $25.1 \%$
$(0.617 \pm 0.019 \mathrm{~kg})$ in group I, $33.7 \%(0.692 \pm 0.025 \mathrm{~kg})$ in group II, $39.7 \%(0.700 \pm 0.028 \mathrm{~kg})$ in group III - compared with the first day of the experiment. Increment in body weight of rabbits for the first, second, and the third weeks on average equalled respectively: $10.9 \%, 3.8 \%, 3.6 \%$ in the control group; $7.0 \%, 10.4 \%, 5.9 \%$ in group I; $8.8 \%, 12.1 \%, 9.6 \%$ in group II; $9.0 \%, 13.2 \%, 12.9 \%$ in group III. Compared with the control group, average daily increment in body weight was $170.6 \%$ in group I, $194.1 \%$ in group II and $194.1 \%$ in group III. Body weight gain during the experiment ( 21 days), compared with the control, equalled $168.1 \%$ in group I, $188.6 \%$ in group II and $190.7 \%$ in group III. At the end of the experiment, we determined significantly higher body weight of rabbits by 1.20 times in group II and 1.14 times in group III compared with the control group.

\section{Discussion}

Morphology of blood. Using mixture of glauconite, succinic, humic and fulvic acids and lactates of zinc, manganese, cuprum, cobalt and iron positively influenced the number of erythrocytes, hemoglobin and mean content of hemoglobin in blood of animals compared with the control group. Our results correlate with the studies of scientists Fedoruk \& Lesyk (2009), and also Pedan (2013), who reported positive effect of such microelements as cobalt, cuprum, manganese, iron on the processes of hematopoiesis. According to Kovalska (1959), anemia caused by deficiency of such elements as iron, cuprum and cobalt in the organism of animals, may manifest in decrease in the content of erythrocytes and content of hemoglobin, and also decrease in the content of total protein and reserve alkalinity (Romanchuk \& Annamuhamedova, 2002), these studies are also confirmed by the results of our experiment. It has to be noted that using dry mixture of glauconite, succinic acid, humic and fulvic acids and lactates of zinc, manganese, cuprum, cobalt and iron with fodder influenced the parameters of hematopoiesis most effectively in rabbits of group II compared with the corresponding parameters of rabbits of other groups (Table 2).

Blood biochemistry. By analyzing all the obtained results of the studies of biochemical composition of blood serum of rabbits, we determined that using a dry mixture of glauconite, succinic acid, humic and fulvic acids and lactates of zinc, manganese, cuprum, cobalt and iron with fodder (group II) stimulated a high level of absorption of proteins, as indicated by parameters of urea and creatinine in blood serum in the conditions of increased catabolism of proteins in animals organism. Increases in overall protein and albumins in blood serum of experimental group II indicate stimulation of protein metabolism in the organism of animals. Significant decrease in GGT concentration suggests that dry mixture of glauconite, succinic acid, humic and fulvic acids and lactates of zinc, manganese, cuprum, cobalt and iron given with fodder causes no damage to liver cells. Increase of inorganic phosphorus and decrease of overall calcium in blood serum allows us to state that phosphorus metabolism in experimental group II was stimulated, while calcium was absorbed more intensely, which manifested in acceleration of energy growth and increase in increments of body weight. Also, we should note that the levels of inorganic phosphorus and overall calcium in blood serum of rabbits of experimental group II were high compared with such of animals of other experimental groups (Table 4). Therefore, the use of dry mixture of glauconite, succinic acid, humic and fulvic acids and lactates of zinc, manganese, cuprum, cobalt and iron with fodder positively influences the parameters of metabolism of proteins, calcium, phosphorus and functional condition of the liver. The results of our studies are consistent with the studies by N. I. Lebedev (1986), who determined that feeding cows with salts of microelements (iodine, zinc, cobalt) normalizes morphological and biochemical parameters of blood, thereby preventing the development of liver cirrhosis (Romanchuk \& Annamuhamedova, 2002). Abd El-Rahim (2017) determined that balanced diet of rabbits, containing sufficient amount of microelements zinc, cuprum, selenium, manganese, cobalt, iron, is essential for correct functioning of the protective mechanisms of the organism of rabbits; the results of our studies correlate with results he obtainedl.

Chemical composition of blood. When studying chemical composition of blood plasma of rabbits, we determined the insignificant effect on metabolism taken by the element we examined in group I that was given the mixture of glauconite, succinic acid, humic and fulvic acids and lactates of zinc, manganese, cuprum, cobalt and iron with water. The best result was 
seen in animals of group II, where dry mixture of glauconite, succinic acid, humic and fulvic acids and lactates of zinc, manganese, cuprum, cobalt and iron was consumed with fodder. Therefore, feeding rabbits with dry mixture of glauconite, succinic acid, humic and fulvic acids and lactates of zinc, manganese, cuprum, cobalt and iron with fodder positively influenced the metabolism of calcium, manganese, magnesium, zinc, iron, cobalt and cuprum.

Antioxidant status. Catalase in the organism of animals decreases the concentration of cytotoxic hydroxile radicals as a result of reducing $\mathrm{H}_{2} \mathrm{O}_{2}$ to water. Increase in catalase activity in blood serum of rabbits of the control group may indicate pro-activation of processes of lipid peroxidation (Brechka et al., 2019). Elokil et al. (2019) determined that addition of zinc and cuprum to the diets of rabbits had a positive effect on the antioxidant properties of the organism and formation of essential aminoacids. When studying activity of catalase in control group II, where the dry mixture of glauconite, succinic acid, humic and fulvic acids and lactates of zinc, manganese, cuprum, cobalt and iron was given with fodder, we observed its significant decrease, which is an indicator of positive effect on antioxidant properties of rabbits' organism. Content of TBA-active products in erythrocytes of rabbits of groups I and III at the end of the experiment increased compared with the control group. At the same time, in group II, we saw a tendency towards decrease compared with the beginning of the experiment, which is a positive expression of lipid peroxidation in the organism. Tsekhmistrenko \& Fedorchenko $(2015,2016)$ gave rabbits vitamin-mineral supplement that contained potassium, phosphorus, sodium, zinc, manganese, iron, iodine, cobalt and selenium, vitamins $\mathrm{A}$, $\mathrm{D}_{3}, \mathrm{E}, \mathrm{K}_{3}, \mathrm{~B}_{1}, \mathrm{~B}_{2}, \mathrm{~B}_{3}, \mathrm{~B}_{4}, \mathrm{~B}_{5}, \mathrm{~B}_{6}, \mathrm{~B}_{12}$, and determined positive changes in the antioxidant system. Furthermore, in presence of ochratoxin $\mathrm{A}$, humic acid improved the functions of the liver and kidneys, decreased pathological changes in these organs and reduced the antioxidant status of the organism to the normal level (Maha et al., 2019).

Increment. Using a mixture of glauconite, succinic acid, humic and fulvic acids and lactates of zinc, manganese, cuprum, cobalt and iron positively influenced increment in rabbits of all experimental groups, but to a different extent. The results of our experiment are coherent with the results obtained by other scientists. Mista et al. (2012) studied the effect of preparation of humic-fatty acids (HFA) on productive indicators and quality of meat of fattening rabbits. Composition of HFA was $80 \%$ of humic-mineral constituents (silicon, aluminium, iron, calcium, sodium, magnesium, phosphorus, manganese, zinc, cuprum, potassium, cobalt, selenium) and $20 \%$ of plant oils (oleic, linoleic, palmic acids). The results of their studies revealed a tendency towards increase in body weight of white New Zealand rabbits and higher coefficient of fodder conversion, improvement of quality of rabbits' meat and increase in content of iron in meat (Mista et al., 2012). Maha et al. (2019) determined that supplementing the diet of rabbits with $0.2 \%$ humic acid improved the food consumption and decreased the ultimate level of mortality among rabbits (Maha et al., 2019).

Al-Sagheer et al. (2020) and Hassan et al. (2021) determined that a zinc-containing food supplement for rabbits improves digestibility of protein and other nutrients, positively influences the conversion of fodder and increment in animals. The greatest gain in body weight of rabbits during the period of study ( 21 days) compared with the first day of the experiment was seen in experimental groups II and III which received dry mixture of glauconite, succinic acid, humic and fulvic acids and lactates of zinc, manganese, cuprum, cobalt and iron with fodder and injected butanol fraction of humic acids. Compared with the control group, significantly higher increment was determined in experimental groups II and III. Kamel et al. (2020) determined a positive influence on antioxidant properties of the organism, morphological and biochemical parameters of increment of rabbits fed with a complex of supplements that included zinc, and those results are also coherent with the results of our experiment.

Therefore, dry mixture of glauconite, succinic acid, humic and fulvic acids and lactates of zinc, manganese, cuprum, cobalt and iron with fodder (group II) stimulated the potential of the organism and had a positive effect on parameters of hematopoiesis, protein and mineral metabolisms and functional condition of the liver, indicating its high efficiency in preventing malfunctioning of mineral metabolism.

\section{Conclusions}

The number of erythrocytes, hemoglobin content and mean hemoglobin content were within the physiological norm throughout the study. Nonetheless, we should note that these parameters were at the lower physiological threshold in all the groups at the beginning of the experiment. At the end of the experiment, we determined that the number of erythrocytes in the blood of rabbits in all groups was significantly higher compared with such of the control. However, the content of hemoglobin in groups I and II was significantly higher, whereas in group III it was significantly lower than such in animals of the control group. The results we obtained allow us to state improvement of hematopoiesis in groups I and II, which is an important indicator for animals that grow and develop.

Level of total protein, albumins, urea and creatinine in blood serum are the parameters of protein metabolism in the organism of animals. During the experiment, those parameters were within the physiological norms for rabbits, though the content of overall protein and albumins in all the groups at the start of the experiment was at the lower physiological thresholds. At the end of the experiment, we determined significantly higher levels of total protein and albumins, as well as urea and creatinine in group II, as compared with the control, suggesting improvement of protein metabolism in that group. At the end of the experiment, we also determined a significantly higher level of total protein in group I compared with the control, whereas the levels of albumins and urea were not significantly different from the parameters of the control group, while the level of creatinine was significantly lower. Protein metabolism parameters in group III at the end of the experiment were not significantly different from such in the control. The results we obtained indicate absence of significant differences in protein metabolism between groups I, II and the control.

Glucose level in blood serum of rabbits during the experiment was within the physiological norms, though at the end of the experiment we determined a higher level of glucose in groups I and II, compared with the control group. Heightened level of glucose was within the physiological norms, therefore suggesting better carbohydrate metabolism in animals of groups I and II than in group III and the control groups. The significantly higher level of inorganic phosphorus simultaneously with lower level of total calcium in blood serum of animals of group II compared with such of the control group at the end of the experiment indicates improvement in calcium and phosphorus metabolisms in the organisms of animals of group II.

Studies of the content of elements in blood plasma in rabbits at the end of the experiment, compared with the control, revealed a significantly higher concentration of calcium in group I. In group II, compared with the control group, at the end of the experiment, we determined significantly higher concentrations of calcium, manganese, zinc, iron and cuprum. In group III, compared with the control, we observed significantly lower concentrations of calciums, zinc, cobalt and magnesium at the end of the experiment. The results we obtained indicate improvements in mineral metabolism in the organisms of animals of group II.

At the end of the experiment, significantly higher body weight of rabbits was recorded in all the groups as compared with the control group. The results we obtained by determining morphological parameters of blood, biochemical parameters of blood serum, content of chemical elements in blood plasma and parameters of antioxidant status in the organism of rabbits allow us to state that using botanol fraction of humic acids stimulates growth of animals. However, in group III, high increment of rabbits was accompanied by decrease in parameters of protein, carbohydrate, mineral metabolism, and also parameters of hematopoiesis, suggesting high increment as a result of the organism of rabbits using all vitally necessary resources in their organism. The aqueous mixture of glauconite, succinic acid, humic and fulvic acids and lactates of zinc, manganese, cuprum, cobalt and iron given with water to group I stimulated weight gain in animals without reduction in the parameters of protein, carbohydrate, mineral metabolisms, and also haemapotoiesis parameters. Intake of dry mixture of glauconite, succinic acid, humic and fulvic acids and lactates of zinc, manganese, cuprum, cobalt and iron with fodder in group II not only stimulated high increment in animals, but positively influenced the parameters of protein, carbohydrate, mineral metabolisms, and also haemapotoiesis.

Thus, the most effective method for prophylaxis of metabolic impairments in white New Zeland rabbits aged 70-95 days was using dry mix- 
ture of glauconite, succinic acid, humic and fulvic acids and lactates of zinc, manganese, cuprum, cobalt and iron in fodder, which positively influenced the hematopoiesis, the state of antioxidant system, protein and mineral metabolisms and increments in body weight.

A promising perspective of the work would be continuation of studying histochemical, histological and immunohistochemical changes in the organs of white New Zealand rabbits using a mixture of glauconite, succinic acid, humic and fulvic acids and minerals and testing those biologically active supplements on animals in farm conditions.

Authors claim no conflict of interests.

\section{References}

Abd El-Rahim, M. I. (2017). The role of nutrition in immunity and diseases resistance in rabbits. Egyptian Journal of Rabbit Science, 27(2), 171-195.

Abdel-Azeem, S., Basyony, M. M., \& Abu Hafsa, S. (2019). Feed intake, antioxidant properties and litter performance affected by multi-nutrient block additive of rabbit does during prevailing heat stress in Egypt. Journal Animal and Poultry Production, 10(5), 133-139.

Abdel-Azeem, S., Hassan, A. A., \& Abu Hafsa, S. (2019). Body weight response, milk production and lipid peroxidation of rabbit does to multi-nutrient block supplementation during summer conditions. Journal Animal and Poultry Production, 10(5), 157-163.

Abdel-Hamid, T. M., \& Farahat, M. H. (2016). Effect of dietary mannan-olygosaccharides on some blood biochemical, haematological parameters and carcass traits in purebred New Zealand White and crossbred rabbits. Animal Production Science, 56, 2133-2139.

Al-Sagheer, A. A., Abdel-Rahman, G., Ayyat, M. S., Gabr, H. A., \& Elsisi, G. F. (2020). Productive performance response of growing rabbits to dietary protein reduction and supplementation of pyridoxine, protease, and zinc. Annals of the Brazilian Academy of Sciences, 92(3), e20180989.

Brechka, N., Bondarenko, V., Morozenko, D., Grushanska, N., Sharandak, P., Selukova, N., \& Danilchenco, S. (2019). The state of prooxidant-antioxidant balance in prostate gland of rats with cryo-trauma and its correction with drugs of natural origin. Georgian Medical News, 296, 91-95.

Carpenter, J. W., \& Marion, C. J. (2018). Exotic animal formulary. Fifth edition. Elsevier, Boston.

Casado, C., Moya, V. J., Pascual, J. J., Blas, E., \& Cervera, C. (2011). Effect of oxidation state of dietary sunflower oil and dietary zinc and $\alpha$-tocopheryl acetate supplementation on performance of growing rabbits. World Rabbit Science, 19, 191-202.

Clauss, M., \& Hatt, J. M. (2017). Evidence-based rabbit housing and nutrition. Exotic Animal Practice, 20(3), 871-884.

Cobanova, K., Chrastinova, L., Chrenkova, M., Polacikova, M., Formelova, Z., Ivanisinova, O., Ryzner, M., \& Gresakova, L. (2018). The effect of different dietary zinc sources on mineral deposition and antioxidant indices in rabbit tissues. World Rabbit Science, 26, 241-248.

Dychok, A. Z., Lesyk, J. V., \& Tsap, M. M. (2018). Rezystentnist' organizmu kroliv za dii spoluk sulfuru [The resistance of rabbit organism for the effect of sulfur complex]. The Animal Biology, 20(3), 16-23 (in Ukrainian).

Ebeid, T. A., Zeweil, H. S., Basyony, M. M., Dosoky, W. M., \& Badry, H. (2013). Fortification of rabbit diets with vitamin $\mathrm{E}$ or selenium affects growth performance, lipid peroxidation, oxidative status and immune response in growing rabbits. Livestock Science, 155, 323-331.

Elokil, A. A., Imbabi, T. A., Mohamed, H. I., Abouelezz, K. F. M., Ahmed-Farid, O., Shishay, G., Sabike, I. I., \& Liu, H. (2019). Zinc and copper with new triazine hydrazone ligand: Two novel organic complexes enhanced expression of peptide growth factors and cytokine genes in weaned v-line rabbit. Animals, 9(12), 1134.

Fedorchenko, M. M. (2016). Dejaki pokaznyky antyoksydantnogo zahystu u plazmi krovi ta pechinci kroliv [Some indicators of antioxidant protection in blood plasma and liver of rabbits]. Scientific Messenger of Lviv National University of Veterinary Medicine and Biotechnologies, 65, 147-152 (in Ukrainian).

Fedoruk, R. S., \& Lesyk, J. V. (2009). Osoblyvosti zhyvlennia kroliv za suchasnyh metodiv vedennia krolivnyctva [Features of rabbit nutrition with modern methods of rabbit breeding]. The Animal Biology, 11, 91-103 (in Ukrainian).

Filippova, O. B., Kijko, E. I., \& Maslova, N. I. (2019). Sorbcija metallov na glaukonite $\mathrm{v}$ uslovijah zheludochno-kishechnogo trakta teljat [Sorption of metals on glauconite in conditions of the gastrointestinal tract of calves]. Russian Agricultural Science, 5, 4448 (in Russian).

Gidenne, T. (2015). Dietary fibres in the nutrition of the growing rabbit and recommendations to preserve digestive health: A review. Animal, 9(2), 227-242.

Gidenne, T., Fortun-Lamothe, L., Bannelier, C., Molette, C., Gilbert, H., Chemit, M. L., Segura, M., Benitez, F., Richard, F., Garreau, H., \& Drouilhet, L. (2017). Direct and correlated responses to selection in two lines of rabbits selected for feed efficiency under ad libitum and restricted feeding: III. Digestion and excretion of nitrogen and minerals. Journal Animal Science, 95, 1301-1312.
Grushanska, N. H. (2017). Vmist vazhkykh metaliv u shersti koriv pivnichno-skhidnoji bioheokhimichnoji zony [The content of heavy metals in the hair of cows in the northern-eastern biogeochemical zone]. Scientific Messenger of Lviv National University of Veterinary Medicine and Biotechnologies, Veterinary Sciences, 73, 154-158 (in Ukrainian).

Hall, E. R. (1952). Investigations on the microbiology of cellulose utilization in domestic rabbits. Journal Microbiology, 7, 350-357.

Hassan, F., Mobarez, S., Mohamed, M., Attia, Y., Mekawy, A., \& Mahrose, K. (2021). Zinc and/or selenium enriched Spirulina as antioxidants in growing rabbit diets to alleviate the deleterious impacts of heat stress during summer season. Animals, 11(3), 756.

Jain, N. C. (1986). Schalm's veterinary hematology. 4th edition. Lea \& Febiger, Philadelphia.

Kamel, D., Abdel-Khalek, A., \& Gabr, S. (2020). Effect of dietary zinc-oxide or nanj-zinc oxide on growth performance, oxidative stress, and immunity of growing rabbits under hot climate conditions. Joumal of Animal and Poultry Production, 11(12), 565-571.

Kiwull-Schöne, H., Kalhoff, H., Manz, F., \& Kiwull, P. (2005). Food mineral composition and acid-base balance in rabbits. European Journal of Nutrition, 44(8), 499-508.

Kunkel, H. O., \& Pearson, P. B. (1948). Magnesium in the nutrition of the rabbit. The Journal of Nutrition, 36(6), 657-666.

Lieshchova, M. A., Bilan, M. V., Bohomaz, A. A., Tishkina, N. M., \& Brygadyrenko, V. V. (2020). Effect of succinic acid on the organism of mice and their intestinal microbiota against the background of excessive fat consumption. Regulatory Mechanisms in Biosystems, 11(2), 153-161.

Maha, S. A. Salama, Wael, A. M. Morsy, Radi, A. Mohamed, \& Samy, A. ElMidany. (2019). Effect of some feed-additives on the growth performance, physiological response and histopatological changes of rabbits subjected to ochratoxin-A feed contamination. Slovenian Veterinary Research, 56(22), 499-508.

Mattioli, S., Rosignoli, P., D’Amato, R., Fontanella, M. C., Regni, L., Castellini, C., Proietti, P., Elia, A. C., Fabiani, R., Beone, G. M., Businelli, D., \& Dal Bosco, A. (2020). Effect of feed supplemented with selenium-enriched olive leaves on plasma oxidative status, mineral profile, and leukocyte DNA damage in growing rabbits. Animals, 10(2), 274.

Mista, D., Rzasa, A., Szmanko, T., Zawadzki, W., Styczynska, M., Pintal, A., \& Kroliczewska, B. (2012). The effect of humic-fatty acid preparation on production parameters and meat quality of growing rabbits. Annals of Animal Science, 12(1), 117-126.

Pedan, L. R. (2013). Profilaktyka vplyvu chynnykiv navkolyshnogo seredovyshha na zdorov'ja za dopomogoju mikroelementu margancju (ogljad literatury) [Prevention of the impact of environmental factors on health with the help of the trace element manganese (literature review)]. Gigiene of Settlements, 62, 326345 (in Ukrainian).

Proença, L. M., \& Mayer, J. (2014). Prescription diets for rabbits. Exotic Animal Practice, 17(3), 485-502.

Raafat, B. M., El-Barbary, A., Tousson, E., \& Aziz, S. W. (2011). Di-mercapto succinic acid (DMSA) and vitamin C chelating potency in lead intoxication, regarding oxidative stress and apoptotic related proteins in rabbits. Journal of Genetic Engineering and Biotechnology, 9(2), 121-131.

Romanchuk, L. D., \& Annamuhamedova, O. O. (2002). Vplyv mikroelementnyh dobavok na okremi pokaznyky fiziologichnogo statusu vidgodivel'nogo molodnjaka v umovah dovgotryvalogo radiacijnogo zabrudnennja u malyh dozah [Influence of microelement additives on separate indicators of physiological status of fattening young in the conditions of long-term radiation pollution in small doses]. Bulletin of the State Agroecological University (Zhytomyr), 2,90-94 (in Ukrainian).

Shtapenko, O. V., Gevkan, I. I., Slyvchuk, Y. I., Dzen, Y. O., Syrvatka, V. Y., \& Matvienko, N. M. (2018). Effect of organic microelements in liposomal form on fertilizing ability and the level of antioxidant reactions of female rabbits. Biotechnologia Acta, 11(4), 50-56.

Sychov, M. J., Holubieva, T. A., Pozniakovskyi, J. V., Andriienko, L. M., \& Holubiev, M. I. (2018). Produktyvnist' molodnjaku kroliv za riznyh rivniv metioninu $\mathrm{v}$ kombikormah [Productivity of young rabbits at different levels of methionine in feed]. Scientific Messenger of Lviv National University of Veterinary Medicine and Biotechnologies, 84, 60-64 (in Ukrainian).

Tsekhmistrenko, S. I., \& Fedorchenko, M. M. (2015). Vplyv vitaminno-mineral'noji dobavky na pokaznyky peroksydnogo okyslennja lipidiv v organizmi kroliv [The effect of vitamin and mineral supplements on lipid peroxidation in rabbits]. Scientific Messenger of Lviv National University of Veterinary Medicine and Biotechnologies, 16, 249-255 (in Ukrainian).

Yan, J. Y., Zhang, G. W., Zhang, C., Tang, L., \& Kuang, S. Y. (2017). Effect of dietary organic zinc sources on growth performance, incidence of diarrhoea, serum and tissue zinc concentrations, and intestinal morphology in growing rabbits. World Rabbits Science, 25, 43- 49.

Zadnipryany, I. V., Sataieva, T. P., Tretiakova, O. S., \& Zukow, W. (2019). Miocardial interstitial matrix as novel target for succinic acid treatment strategies during experimental hypobaric hypoxia. Russian Open Medical Journal, 8(2), e0201. 